\title{
On the Change of Regime in Public Finances and the Theoretical and Practical Features of the Hungarian Method
}

\section{Reflections on a Book by Csaba Lentner Entitled Change of Regime and Financial Policy}

SUMMARY

In the period after the 2007-2008 crisis, the practical methods and academic schools advocating that economic growth and financial stability are maintainable through the state's proactive and reasonable economy engineering also strengthened in Hungary. One of the most prominent and trendsetting professors of these efforts is Csaba Lentner, who outlined, in his book Change of Regime and Financial Policy, ideas worth familiarizing with and inviting professional discussions. More than a quarter of a century after the change of regime in Central and Eastern Europe, the applied economic policy models and system taxonomies are repeatedly compared and new comparative methods emerge overwhelmingly, con- firming the significance of and academic grounding for statecraft, including public financing and good governance.

Journal of Economy Literature (JEL) codes: B1, E5, E6, F4, G01, H2, H6, P3, Q1 Keywords: public finances, planned economy, neoliberal concept of transition to a market economy, life after the subprime crisis, unconventional monetary and fiscal mechanisms, Central and Eastern Europe, Hungary

\section{INTRODUCTION}

The author presents the main economic policy developments between the end of the socialist planned economy and 2004, and then in the period between 2010 and

Dr ERnố HuszTi, Honorary University Professor, Corvinus University of Budapest, Honorary Professor, Budapest Business School, Doctor of the Hungarian Academy of Sciences (husztierno@t-online.hu). 
2016 (making reference to the fiscal exhaustion between 2002-2010). The analysis of the two disparate periods provide a good opportunity for the evaluation of the characteristic feature of Hungary's various financial policies.

The essence of the book is a comparison of the repressed role of the state (or its theoretical alternative practiced at that time) seen from the moment of the change of regime, on the one hand, and the theory and practice of the unconventional, in other words, proactive government action. Ultimately, three decades are overviewed, and they include, at the last two-thirds (in 2007-2008), a grave world economic crisis that impeded the appropriate management of Hungary's economy development and rendered adjustment to the changes more difficult, sometimes even appearing impossible. All these placed Hungarian fiscal and monetary policy under double pressure, which had to be fended off. The author gets the point: which are more reasonable in an emerging market economy (once pursuing a Soviet-type planned economy), i.e. in Hungary: the conventional economic policy instruments fitting in the neoliberal system of the Washington Consensus or the regulatory and controlling toolkit of a proactive state?

\section{DYNAMICS IN PUBLIC FINANCES}

With the exception of its last chapter, the assumptions made in a successful book of an identical title (Change of Regime and Financial Policy) and published by Akadémiai Kiadó in 2005 are repeated to confirm them and present the need for and implementation of changes. ${ }^{2}$ The author presents the achievements of the pe- riod and his expectations of key changes in finances, as an overview was indispensable, and some of them (as it becomes clear from the last chapter of the book) still remain unsolved to this date. The author raised a series of pivotal questions in relation to privatisation, ${ }^{3}$ the transformation of agriculture, taxation and the one-tier banking system, the European Union, economic growth, financial equilibrium, etc. He did so before the onset of the global economic crisis, which had lasting impacts felt to this very day. $\mathrm{He}$ was compelled to highlight the problem of increasing government indebtedness, and the most significant unsolved issues of the financial sector that are in harmony with the national financial policy. "Raising the budget funds required for the permanent disbursement of government subsidies, and the elaboration of financial policy instruments providing a basis for raising liquid funds from commercial markets indispensable for lending to businesses are among the most urgent duties in the new millennium", the author thought in 2005 and his ideas proved to be forward-looking (Lentner, 2005a, p. 233).

In preparation for the first part of the book, the author published several studies between 1990 and 2005. ${ }^{4}$ Already at that time he was seeking solutions for problems like the need to set up an efficient system of financial institutions, the insufficiently clarified questions of Hungary's accession to the European Union relating to the financial sector, the challenges Hungary may face at the turn of the millennium, the evaluation of the financial strategy implemented at that time, the possible solutions that may be included in the political and economic 
toolkit, etc. Already back then (in 2005) he raised the possibility (or need) of departing from the wonted financial policy principles and methods, and solidified economic constraints.

I consider it very important that he includes the general government as part of fiscal policy and practice (just as I do and profess), as no efficient financial policy can be developed without this approach. The author's demand for the development of an adequate tax policy through the enforcement of the "needed but sufficient" principle is especially important, as in the absence of the latter permanent GDP growth may be impeded.

After the change of regime, the slight contradiction in financial conditions was manifest mainly in the hectic budget changes. This was solved by a series of budgetary reforms $(1995,1998,2000-$ 2002), however, for various reasons they remained below the expectations. In that period the activity of the two-tier banking system could already be evaluated: if the government and the National Bank of Hungary (acting as a "bank of banks") correctly established credit relations and the conditions of lending, appropriately regulated the monetary base required for the economy, and if it was sufficiently prepared for the interrelationships to be necessarily set up in relation to the international payment transactions and with the state (budget).

BANKING POLICY AND ECONOMIC POLICY UP TO THE 2004 ACCESSION TO THE EU

In view of the above, the author goes into details as to the structural problems of the two-tier banking system established after 1987, addressing the difference between the financing policies of foreign- and Hungarian-owned banks and the companies and corporations operating in the key sectors of the national economy. As a result, numerous companies without sufficient coverage were granted plenty of funds in the form of loans, while others, primarily small and medium-size enterprises, were unduly elbowed out of lending. All this adversely affected both industry, especially agriculture, ${ }^{5}$ and services, including employment, which resulted in enormous losses in government revenues, further increasing the budget debt. Meanwhile, the financial institutions still in Hungarian hands, already undergoing transformation and struggling with numerous weaknesses, suffered enormous losses as a result of their freezing of their allocated loans. Due to its significance, the author returns to this problem in various contexts, as in his opinion Hungary became particularly exposed to international capital, increasing the threat of an economic paralysis.

The role of gold in the central bank's reserve appreciates at certain intervals, and is given less priority at other times. I agree with the author that in the twotier banking system recently introduced in Hungary at that time, the central bank also followed the international trend of the day, by considerably reducing its gold reserve, while e.g. the US did not take any such action. ${ }^{6}$ Although we witnessed a doubtless demonetisation of gold, the author clearly calls the attention to the need to strengthen the role of gold among the assets that serve as central bank reserves. The reason is that he was afraid that private capital would ceaselessly purchase the central banks' gold reserves, and thus they would be withdrawn 
from the national monetary aggregates. If this actually happens, central banks, in this particular case, the National Bank of Hungary, lose one of their most important market controlling instruments, and the purchasing power of currencies (in this case, the forint) would depreciate considerably. At present, particularly in the light of the most recent world economic crisis, to contest the soundness of these assumptions might be dangerous.

Currently, bank transfers cannot be skipped during international capital transfers, they are simultaneously national and international, due not merely to their ownership structures but also to their financing, capital accumulation functions and role played as incentives to save. The author reminds us that in the interest of our competitiveness, membership in the EU notwithstanding, the country cannot dispense with strengthening its central banking and commercial banking positions, a favourable modification in the national wealth, and the reinforcement of the instruments used for state intervention, not merely for the purpose of defence but also to bring the adjustment mechanism to success.

Based on several decades of my central banking experience, I can only agree with the author, who quotes the opinion of Imre Menyhay: "the current liberal variety of democracy brings the powerful and unilateral appreciation of the individual desire to make money and wealth in its train, which... might manifest to the detriment of the society's community values" (Menyhay, 1998). All this entails increase in insolvency, in the number of cash payments circumventing banks, and aggressive personal endeavours to make money and wealth. Actually, this was the fact that made thing difficult for the budget and the central bank. Nevertheless, I must add that this was not some conscious "behaviour based on theory", the stakeholders simply abused the situation that had evolved, as the support programmes launched by the state became dependent on and monetary policy was characterised by an ad hoc operation adjusted to government cycles. This made both continuity and transparency unpredictable, rearranged the market in favour of businesses operating with foreign backing and to the detriment of Hungarian ones. As a result, the latter were compelled to permanent borrowing, even in the case of uncertain repayment capacities, and this caused serious damage to the intermediaries in the banking system. In the author's opinion all this greatly hindered and simultaneously undermined the creation of a middle class in Hungary on the basis of independent domestic businesses.

As Hungary had traditionally been compelled to raise capital from abroad, in his assumption the Hungarian economy is fundamentally dependent on the global economy, and thus the options of a spectacular development and of recession are given simultaneously, and give rise to vulnerability in economic and social relations and a weak capability to enforce national interests. Thus particular attention must paid to the conditions and opportunities of using external resources, and to fiscal, monetary and, not least, social stability.

The author thinks that "During the decade past, the world economy and more specifically, the European Union have become points of attraction and directions of closing the gap" (Lentner, 2016, p. 278). 
However, this compelled Hungarian economic policy to change the paradigm, irrespectively of the nature of developments in the world economy. The official economic policy coined this as the "Hungarian model", focussed, in the author's opinion, on a "conservative" state-engineered economic policy, the maintenance of the external and internal financial equilibrium, and ensuring an appropriate external capital and financial stability.

As an indispensable precondition of the above requirements, Hungary must have a relationship with the international capital markets and financial institutions. The several price explosions seen in the world market prices from the early 1970 s had serious impacts on all the continents of the globe. Countries were divided into two major groups: those that instantly responded to the crises developed their economic policies with due consideration to them, contained growth (primarily investments), tightened their fiscal and monetary policies to prepare for the expected recession, modified the conditions of distribution and redistribution, increased price levels etc., while those that considered the grave consequences of the crisis as merely transitional and made a kind of fetish of the trend that had evolved.

Hungary belonged to the latter, and "once the fixed exchange rate system collapsed, real sector performances are considerably exceeded by financial sector growth overheated by speculation" (Lentner, 2016, p. 290). Nearly after a decade, in the absence of the required internal accumulation, Central and Eastern European countries made efforts at closing the gap to their external markets using external development resources. The capital adequacy of the banking system, which had been restructured and turned into a two-tier system, proved to be insufficient to meet the increasing demand for lending, and this led to the relocation and market acquisition of foreign banks. In our days (in 2017), however, the relationship between financial institutions and their customers may already be considered consolidated, thanks partly to the consumer protection activity of the National Bank of Hungary, as "the MNB forces financial service providers to act fairly, placing emphasis on the increased protection of defenceless consumer groups" (Lentner, 2016, p. 316). The European Union has also recognised the necessity of modernising financial regulation, and stressed the significance of a more efficient banking regulation. The author gives practical examples from the period preceding 2013, when in the absence of sufficient authorization the Hungarian Financial Supervisory Authority was unable to make efficient achievements.

\section{ENFORCEMENT OF THE PROACTIVE STATE} MODEL

In the last chapter of the book, the author sums up the historical background, reasons, aims and achievements of a change of regime in public finances, in comparison to certain international cases. ${ }^{7}$ An implicit agreement has been reached among the economists advocating diverse views on the absence of a coherent economic policy, the unsatisfactory management of the 2008 crisis, the deficiencies of power techniques, the quality of state involvement, the role played by international economy and the financial institutions, state indebted ness and the draining of state property, etc. "Hungary has sunk into a complete debt trap. At the 
level of the general government and of families and households" (Lentner, 2016, p. 304) ${ }^{8}$ In the author's opinion, the diverse expert conclusions clearly reveal that "only a strong and well-organised state capable of proactively intervening in economic and social procedures can efficiently enforce the interests of the national economy, the market participants and families" (Lentner, 2016, p. 304). Due to the essential assumptions and the presentation of the unconventional instruments and methods, Csaba Lentner's book can be rightly listed among Hungarian scientific works of taxonomic significance. ${ }^{9}$

Then the author goes on to give details of the current state of the more important components of fiscal policy, such as an acceptable share of all in taxation, the policy of opening up new markets, the reduction of public utility fees and personal income taxes, the moderation of the burdens of FCY loan debtors and SMEs, the favourable developments in the labour market, and not least, the favourable position of the external debt and the budget. Based on all these he establishes that: "Fiscal consolidation provided a good basis for launching a change in monetary policy"10 (Lentner, 2016, p. 308), which comprised four elements:

1) mitigation of the base rate,

2) the funding for growth,

3) the self-financing and

4) the corporate social responsibility programmes.

In addition, the National Bank of Hungary assumes responsibility for the environment, the society and sustainable long-term development, but does not abandon education, science and financial awareness raising, consumer protection etc. either, in other words, it sup- ports value preservation and creation.

Thus the author ascertains that as a result of the fiscal consolidation that had been accomplished by 2013, and of the change in the monetary regime, between 2013 and 2016 the financial position of the various groups of money owners (budget, local councils, companies and the population) could be considered balanced, while the banks and companies with foreign interest had to make sacrifices. The need for a change of perspective in economic policy, claimed by the author in $2005^{11}$ on the basis of theoretical functions set up in an empirical approach for the portfolio (government securities market) and foreign direct investments, was proven in 2016, as evidenced in the last (20th) chapter of Lentner's book. In 2005, the author wrote that the foreign direct investment flowing to Hungary from the beginning of the change of regime had, in a certain sense, dynamised the economy, however, the tax policies applied byt the various governments only imposed very moderate taxes on international companies and investments, which after some time, in terms of contribution to GDP, gave the backbone of the Hungarian economy. The tax revenues not received by the budget and the weak tax payment capacity of state-owned companies and Hungarian SMEs against a background of increasing financial demands by those falling out of the labour market, domestic companies, local governments and the social supply system, generated a deficit in public finances and consequently, sovereign debt. A financial deficit evolved along with a debt trap arising from the insufficient budget organisation, which was then followed by social deficit and a social dissatisfaction trap. In order to raise funds to cover the grow- 
ing deficit, an increasing amount of foreign loan had to be borrowed, and after some time the FDI received in Hungary was exceeded by the amount of funds allocated to the market of government securities. The debt service resulting from the increasing indebtedness deprived welfare, healthcare, education and a more pronounced support to Hungarian businesses of considerable funds. Thus essentially, foreign direct investment operating at minimum taxes (unadjusted to the actual tax payment capacity) did drive the economy (GDP and exports), but simultaneously it generated government deficit with the "approval" of the inappropriate economic policy applied by the government. The ever rising interests paid on the foreign loans (portfolio investments) raised to finance the increasing current deficit and government debt reduced the stability of the macroeconomic environment, and the funds available for training employees and improving the healthcare system. In order to improve the deteriorating situation, the author recommended (back in 2005) that the economy should be consolidated by levying taxes in adjustment to the tax payment capacity of foreign direct investments and providing tax benefits to Hungarian residents to rev up solvent demand, consumption and thus the economy (based on J. M. Keynes's model). After this improvement in the stability of public finances, as a result of healthcare and education run from more money, foreign banks and corporations, which have sacrificed part of their profits in the budget balancing process, will subsequently be able to have access to higher trained and healthier employees, and thus their presence in Hungary will be given new content and a more favourable climate for long-term operation. The temporary profit sacrifices repay as a result of the new tax policy. Thus instead of extensive conditions (tax benefits), the relocation of foreign investors can be improved through qualitative factors (more stable general government, higher trained and healthier labour). This is, in essence, the author's theory of the relocation and integration of international companies (from 2005), which can also be interpreted as the theoretical foundation of the economic policy that unrolled after 2010 and which was proven correct by the author in his new book. ${ }^{12}$

The book presents the readers with the changes and dynamic in Hungarian economic policy, provides a theoretical explanation for and confirmation of the prevailing practice, in numerous cases also including criticism. The author himself is a practical expert who has been active during the past decades, but worthy of a scientist well-established as a university professor, he analyses the intervention methods used by economic policy and the inseparable financial management, and their social impacts. In the publisher Akadémiai Kiadó's (official) notice released in 2005 (for the first publication), the author's readiness and ability to change was marked as his most outstanding merit and virtue, and this also characterises the Hungarian economy. ${ }^{13}$ Recalling the communication of Akadémiai Kiadó, now in 2016 and 2017, when the enlarged monography, accessible in a printed and an electronic version, is quoted as a reference, it can be repeated that a solid piece of work has been made. ${ }^{14}$

Csaba Lentner's overview of several decades presents us with numerous examples within the scope of the main trend, and they require thorough considera- 
tion and a profound knowledge of fiscal and monetary processes. He explains his ideas on the basis of an enormous Hungarian and foreign literature, and even skilled practitioners will not find it easy to read. This, however, does not reduce the author's merits and the book can serve as an excellent source for those studying this topic or are interested in Hungary, or more generally, in the transformation of the post-soviet region.

\section{Lentner, Csaba (2016): Rendszerváltás és} pénzügypolitika [Change of regime and financial policy]. Akadémiai Kiadó, Budapest, 336 pages.

\section{Notes}

1 The author headed a department at the National Bank of Hungary for several decades and he was one of the fathers of the theoretical foundations underlying the two-tier bank system. In the first half of the 1990s he acted as the managing director of the Hungarian Credit Bank, and then as the Deputy CEO of the Hungarian Trade and Credit Bank. He is an honorary university professor at the Corvinus University of Budapest and at the Budapest Business School. He received the Silver Cross of Merit of the Republic of Hungary. Field of research: banking regulation, measuring money demand and supply, and monetary governance. Major works: Antiinflációs útkeresés - monetáris politika és gyakorlat Magyarországon [Anti-inflationary reflection - monetary policy and practice in Hungary]. KJK, Budapest, 1987; A makropénzügytan alapjai [Fundamentals of macroeconomic finances]. Veszprémi Egyetemi Kiadó, Veszprém, 1998; Banktan [Banking]. Tas Kiadó, Budapest, 2002; Pénzpiacok szabályozása Magyarországon [Regulation of financial markets in Hungary]. (Co-author with Csaba Lentner, Pál Kolozsi and others), Akadémiai Kiadó, Budapest, 2006; Egy valuta története [The story of a currency]. L'Harmattan Kiadó, Budapest, 2011; Bankmenedzsment. Bankszabályozás, pénzügyi fogyasztóvédelem [Bank management: Bank regulation, financial consumer protection]. (Coauthor), Nemzeti Közszolgálati és Tankönyv Kiadó, Budapest, 2013. Publication presenting his academic achievements: Pénzügypolitikai stratégiák a XXI. század elején. A pénzügyi intézményrendszer, a tudomány és a felsôoktatás szolgálatában [Financial policy strategies in the early 21 st century: The system of financial institutions in the service of science and higher education]. A book in honour of Professor Ernố Huszti on his 75th birthday, ed. Csaba Lentner, Akadémiai Kiadó, 2007.

2 “...I confirm that my criticism and predictions for the future have stood the test of time and are still correct today..." (Lentner, 2016, p. 5).

3 In relation to the privatisation procedures taking place in Central and Eastern Europe, he quotes the apposite idea of the Polish economist, Lewandowsky, which says that "privatisation is the sale of companies of unknown values and not owned by anybody to buyers who do not have money" (Lentner, 2016, p. 14). The author had a similar opinion: "...according to the government's solutions, ultimately the Hungarian nation will remain without any assets at all, but the internal and external sovereign debts will continue to rise..." (Lentner, 2016, p. 21).

4 See literature at the end of the article.

5 In 2005, agriculture provided no more that 4 percent of GDP and 8 percent of the country's total export, and the number of employees dropped significantly in this sector.

6 I myself believe any gold reserve kept in the central bank's vault in addition to a specific amount (required for safety reasons) is just as "dead" as the vault, it does not generate any income, and so it should be reasonably allocated.

7 In Csaba Lentner's interpretation, in the fiscal policy line, the change of regime in public finances took place in 2010, following more than two decades of chronic weakness in public finances under a neoliberal management, after its fate was sealed by the $2007-2008$ crisis. In the author's terminology the expression "change of public finance regime" includes the transformation of taxation and a shift in government finances towards a stricter regulation and central economy engineering after 2010, and the policy of the central bank operating with multiple mandates after 2013.

8 The author considers consolidation successful for all the three areas, in a manner that generates a combined impact. 
9 Without attempting to be exhaustive: Matolcsy, 2015; György and Veress, 2016; Pogátsa, 2016.

10 This was reinforced by the communication of the Monetary Council of the National Bank of Hungary, published in the second half of 2010, stating that "it can be established that as a result of the global upturn, recession has come to an end in Hungary".

11 Lentner, 2005, Chapter 17, with special focus on pp. 265-267.

12 Moreover, certain segments in the new type of economic policy (bank policy, bank regulation, public finances, consolidation) are also analysed in the author's books published after 2010.

13 https://akademiai.hu/1881/gazdasag/tovabbi_ konyvek/rendszervaltas_es_penzugypolitika_1.

14 In view of the significance of the content of the book, owing to the good offices of publisher, the author's ideas are also accessible for reading in an electronic format at: https://mersz.hu/dokumentum/dj231rep__1/.

\section{REFERENCES}

Csermák, Károly (2005): Lentner Csaba: Rendszerváltás és pénzügypolitika [Change of regime and financial policy]. Tér és Társadalom, Vol. 19, No. 3-4, pp. 231-232.

Fonda, Ferenc (2006): Rendszerváltás és pénzügypolitika [Change of regime and financial policy]. Valóság, Vol. 49, No. 8, pp. 106-110.

György, László and Veress, József (2016): The Hungarian Economic Policy Model After 2010. Public Finance Quarterly, Vol. 61, No. 3, pp. 360-381.

Hauser, Siegfried and Lentner, Csaba (2003): Immobilienleasing: Mieten Statt Kaufen. Entwicklung des Deutschen and Ungarischen Marktes. Input, No. 1, pp. 26-29.

Huszti, Ernố (1987): Antiinflációs útkeresés - monetáris politika és gyakorlat Magyarországon [Antiinflationary reflection - monetary policy and practice in Hungary]. Közgazdasági és Jogi Könyvkiadó, Budapest,

Huszti, Ernô (2011): Egy valuta története... A forint forgalma a stabilizációtól az euró elôszobájáig [The story of a currency... Forint circulation between stabilisation and the hallway to the accession to the euro area]. L'Harmattan and Zsigmond Király Fốiskola, Budapest.
Lentner, Csaba (1991): A mezôgazdasági hitelek árnyoldalai [The dark sides of agricultural credits]. Gazdálkodás, Vol. 35, No. 12, pp. 29-33.

Lentner, Csaba (1996): Ki fizeti (meg) a privatizációt? [Who pays for privatisation?]. Gazdaság és Társadalom, Vol. 7, No. 3-4, pp. 36-50.

Lentner, Csaba (1998): Dilemmas of Hungary's Agricultural Future Contrasted with Its Historical Background and Developed Market Economy Models. In: Gidai, Erzsébet (ed.): On the Eve of the 21st Century: Challenges and Responses. Akadémiai Kiadó, Budapest, pp. 175-185.

Lentner, Csaba (2000): Ezredfordulós dilemmák: agrárpolitika a pénzügypolitika fogáságában [Quandaries at the turn of the millenium: ensnared by agricultural and financial policies]. In: Magyarország politikai évkönyve [Hungary's political almanac]. Vol. 13, No. 1, pp. 178-189.

Lentner, Csaba (2001a): Pénzügyi kihívások az ezredforduló Magyarországán [Financial challenges in Hungary at the turn of the millennium]. In: Lentner, Csaba (ed.): Pénzügyi szilánkok [Financial Splinters]. Soproni Pénzügy Szakos Egyetemi Hallgatók Szakkollégiuma, Sopron, pp. 9-54.

Lentner, Csaba (2001b): Magyarország európai uniós csatlakozásának nyitott kérdései - különös tekintettel a pénzügyi szektorra [Open questions of Hungary's accession to the European Union, with special regard to the financial sector]. In: Lentner, Csaba (ed.): Tudományos értékeink [Our scientific values]. Soproni Pénzügy Szakos Egyetemi Hallgatók Szakkollégiuma, Sopron, pp. 53-101.

Lentner, Csaba (ed.) (2001c): Tudományos értékeink [Our scientific values]. Soproni Pénzügy Szakos Egyetemi Hallgatók Szakkollégiuma, Sopron.

Lentner, Csaba (ed.) (2001d): Pénzügyi szilánkok [Financial splinters]. Soproni Pénzügy Szakos Egyetemi Hallgatók Szakkollégiuma, Sopron.

Lentner, Csaba (2002a): A nemzetközi tôkepiacok és pénzügyi intézmények - közép- és kelet európai szemmel [International capital markets and financial institutions with the eye of a Central and Eastern European]. Pénzügyi Szemle, Vol. 47, No. 5, pp. 471-47.

Lentner, Csaba (2002b): A hazai vállalkozásokat erôsítô gazdasági programok társadalmi hatásai - az egzisztenciahiteltôl a Széchenyi Tervig [Social effects of economic programmes to 
strenghten Hungarian businesses - start-up from loans to the National Development Programme). Valóság, Vol. 45, No. 8, pp. 60-68.

Lentner, Csaba (2003): A pénzügyi intézményrendszer létrehozása (1990-2001) [Setting up financial institution, 1990-2001]. In: Baross, Gyula et al. (eds.): A pénzügyi intézményrendszer Magyarországon [Financial institutions in Hungary]. Nebuló 2001 Kiadó, Budapest.

Lentner, Csaba (2005a): Rendszerváltás és pénzügypolitika [Change of regime and financial policy]. Akadémiai Kiadó, Budapest.

Lentner, Csaba (2005b): Magyar pénzügyi stratégiák az ezredfordulón [Hungarian financial strategies at the turn of the millennium]. In: Gidai, Erzsébet and Lentner, Csaba (eds.): Magyarország jövôje: Hungaria in aeternum [The future of Hungary]. Nyugat-Magyarországi Egyetem Közgazdaságtudományi Kar, Sopron, pp. 73-97.

Lentner, Csaba (2013a): Közpénzügyek és államháztartástan [Public Finances and the Study of the General Government]. Nemzeti Közszolgálati és Tankönyv Kiadó Zrt., Budapest.

Lentner, Csaba (2013b): A bankszabályozás tudományos rendszertana és fejlődéstörténete [Taxonomy and history of banking regulation]. In: Lentner, Csaba (ed.): Bankmenedzsment. Bankszabályozás, pénzügyi fogyasztóvédelem [Bank management: Bank regulation, financial consumer protection]. Nemzeti Közszolgálati és Tankönyv Kiadó, Budapest, pp. 27-86.

Lentner, Csaba (2015a): The New Hungarian Public Finance System - in a Historical, Institutional and Scientific Context. Public Finance Quarterly, Vol. 60, No. 4, pp. 447-461.

Lentner, Csaba (2015b): The Structural Outline of the Development and Consolidation of Retail Foreign Currency Lending. Public Finance Quarterly, Vol. 60, No. 3, pp. 297-311.

Lentner, Csaba (ed.) (2015c): Adózási pénzügytan és államháztartási gazdálkodás. Közpénzügyek és államháztartástan II [Fiscal policy and the management of public finances: Public finances and the study of the general government II]. NKE Szolgáltató Kft., Budapest.

Lentner, Csaba (ed.) (2015d): A devizahitelezés nagy kézikönyve [The great book of foreign currency lending]. Nemzeti Közszolgálati és Tankönyv Kiadó Zrt., Budapest.
Lentner, Csaba (2016): Rendszerváltás és pénzügypolitika. Tények és tévhitek a neoliberális piacgazdasági átmenetrôl és a 2010 óta alkalmazott nem konvencionális eszközökrôl [Change of regime and financial policy. Facts and myths about the neoliberal concept of transition to a market economy and the unconventional instruments used in public finance since 2010]. Akadémiai Kiadó, Budapest.

Lentner, Csaba (2017a): Kormányzati és közigazgatási feladatok közgazdasági és közpénzügyi megalapozá$s a$ [Economic and public finance undamentals of government and public administration duties]. Dialóg Campus Kiadó, Budapest.

Lentner, Csaba (2017b): New Concepts in Public Finance After the 2007-2008 Crisis. Economics $\mathcal{E}^{2}$ Working Capital, No. 1-4, pp. 2-8.

Lentner, Csaba; Huszár, Lilla and Kolozsi, Pál Péter (2003): The Hungarian Finance Sector and the European Integration. In: Delener, Nejdel and Chao, Chiang-nan (eds.): Challenging the Frontiers in Global Business E $\mathcal{F}$ Technology: Implementation of Changes in Values, Strategy $\mathcal{E}^{\circ}$ Policy. GBATA Int. Conference Reading Book, GBATA Global Business and Technology Association, New York, pp. 821-829.

Lentner, Csaba; Huszti, Ernô; Tarpataki, János and Seregdi, László (2002): Bankszabályozás [Banking regulation]. Soproni Pénzügy Szakos Egyetemi Hallgatók Szakkollégiuma Alapítvány, Sopron.

Lentner, Csaba; Turján, Sándor and Varga, József (eds.) (2001): Költségvetési pénzügyek [Public Budgeting]. Nebuló 2001 Kiadó, Budapest.

Matolcsy, György (2015): Egyensúly és növekedés [Balance and Growth]. Kairosz Kiadó, Budapest

Menyhay Imre (1998): Adalékok Káin „esti meséjéhez”. Gazdaság és szocializáció a jelenkori liberális társadalomban [Contributions to Cain's bedtime story. Economy and socialisation in the current liberal society]. Akadémiai Kiadó, Budapest.

Pogátsa, Zoltán (2016): Magyarország politikai gazdaságtana. Az északi modell esélyei [Political economics in Hungary: Chances of the northern method]. Osiris Kiadó, Budapest.

Prugberger, Tamás (2005): Lentner Csaba: Rendszerváltás és pénzügypolitika [Csaba Lentner: Change of regime and financial policy]. Jogelméleti Szemle, Vol. 6, No. 3. 